\title{
Socio and ethno-cultural embeddedness of transnational Nigerian immigrant entrepreneurs in Ghana
}

\author{
Thomas Antwi Bosiakoh ${ }^{1 *}$ (i) and Bernard Acquah Obeng ${ }^{2}$
}

\author{
${ }^{*}$ Correspondence: \\ bosiakoh@gmail.com \\ ${ }^{1}$ Department of Sociology, \\ Macquarie University, Sydney, \\ Australia \\ Full list of author information \\ is available at the end of the \\ article
}

\begin{abstract}
Transnational Nigerian immigrant entrepreneurs have been in Ghana for a long time, operating by utilizing a wide range of resources available to them. Key among these resources are their own socio and ethno-cultural norms which have yet to be explored in the existing scholarship. We explore these patterns and norms in the articulation of transnational entrepreneurship among these immigrants in Ghana. We do this by relying on qualitative data gathered through in-depth interviews, observations and market conversations - with 41 Nigerian immigrant entrepreneurs in Accra, Kumasi, and Ashaiman. We argue that these transnational Nigerian immigrant entrepreneurs in Ghana are embedded in their own 'socio and ethno-cultural heritage'. This argument is anchored in multiple logics. First is the notion of transnational entrepreneurial activity that is ethnically and culturally inspired. Secondly, these entrepreneurship activities are inextricably embedded in informality and intensely rely on informal power brokerage system. Thirdly, there is an embeddedness in the entrepreneurs' own traditional apprenticeship system. These lines of socio and ethno-cultural embeddedness provide useful pathways for understanding not only the operations and future prospects but also the patterns of transnational (mixed) embeddedness of the Nigerian immigrant entrepreneurs in Ghana.
\end{abstract}

Keywords: Social embeddedness, Ethno-cultural embeddedness, Transnational immigrant entrepreneurs, Nigerian immigrant entrepreneurs, Ghana, Nigeria

\section{Introduction}

The mixed embeddedness approach has seen application in different contexts and in different domains since its export into the field of immigrants' entrepreneurship in the late 1990s by Dutch scholars Kloosterman et al. (1999). Admittedly, the utility of this approach has been in its broader and all-encompassing pathway for explaining immigrants' entrepreneurship. In its 20-years of application, scholars have brought tremendous insight to the approach from the domain of economy (Barrett et al., 2002), state structure (Jones et al., 2014; Kloosterman, 2003a) and history (Peters, 2002), among others like politics, policy and law. Moreover, the use of the approach to understanding immigrant entrepreneurs has tended to focus on western settings like those in Europe author(s) and the source, provide a link to the Creative Commons licence, and indicate if changes were made. The images or other third party material in this article are included in the article's Creative Commons licence, unless indicated otherwise in a credit line to the material. If material is not included in the article's Creative Commons licence and your intended use is not permitted by statutory regulation or exceeds the permitted use, you will need to obtain permission directly from the copyright holder. To view a copy of this licence, visit http:// creativecommons.org/licenses/by/4.0/. 
(Barrett et al., 2002; Jones et al., 2014; Kloosterman, 2003a;), Australia (Peters, 2002), US (Chacko, 2015; Price \& Chacko, 2009) and elsewhere (Aliaga-Isla \& Rialp, 2013). Despite these efforts, there are yet, many aspects of the theory that suffer in terms of empirical application including how immigrants' own social, ethnic and cultural patterns implicate their entrepreneurial careers. But perhaps more important in the discourse on mixed embeddedness' application is the idea of context, i.e. the different contexts and settings that scholars have focused on, in their empirical application of the theory. We argue in this paper that, thus far, the empirical application of the mixed embeddedness theory has tended to focus on North American and to a much greater extent, the European contexts, to the neglect of other equally important geographical regions, particularly the African region.

Therefore, in this paper, we provide two important drifts to enrich the scholarship on mixed embeddedness and immigrants' entrepreneurship. First, we bring insight to the approach from the social and ethno-cultural domains of immigrants in the articulation of their entrepreneurship. We draw on the narratives of Nigerian immigrants in Ghana and the ways in which their social and ethno-cultural realities provide structuring influence on their entrepreneurship in the country. This is important for the specification and representation of the mixed embeddedness approach for explaining immigrants' business set-up and operation in their destination countries. Our second drift addresses the lacunae of mixed embeddedness and immigrant entrepreneurship research in lesser known context, Ghana in West Africa with migration actors from Nigeria. The paper thus broadens the contextual scope of mixed embeddedness' empirical application.

\section{The embeddedness approach to immigrants' entrepreneurship studies}

The embeddedness approach to immigrants' entrepreneurship studies, which builds on the agency-structure interactive model of Waldinger et al. (1990) and further draws on Granovetter's (1985) social embeddedness construct, postulates a nexus between immigrant entrepreneurs' own characteristics and the wider socio-economic and political contexts within which they operate (Kloosterman, 2010; Kloosterman \& Rath, 2001; Kloosterman, et al, 1999). The approach venerates how, in simple terms, economic activities of immigrants are rooted not just in the micro-level characteristics of the immigrants, including their social embeddedness but also in the wider meso and macrostructures of the destination country. The approach incorporates multiple realities of social embeddedness, market dynamics or economic embeddedness and politico-institutional embeddedness in explaining immigrant entrepreneurship because these layers of realities impact the decisions and choices of immigrants regarding the economic activities they can and will pursue (Jones et al., 2014; Kloosterman et al., 1999; Kloosterman, 2003a, 2003b, 2010; Moyo, 2014).

Kloosterman et al., (1999, p. 253) have argued reasonably that immigrants' expectation of upward social mobility in destination countries should be understood by considering 'their embeddedness in the socio-economic and politico-institutional environment of the country of settlement'. This somewhat implies that the articulation and pursuit of the 'migratory goals and expectations' are embedded in the social, economic, political and institutional spaces and arrangements of the migration destination. This is an important sermon to the mixed embeddedness treatise in immigrant entrepreneurship, 
a treatise which argues that immigrants' entrepreneurship be grounded, not just in the immigrants' own resources of ethno-social capital, but also, in the operating conditions of their contexts (including political-economic environment, legal, and policy) of the immigration society. Kloosterman and Rath (2001, p. 190) also explain that the (mixed) embeddedness approach focuses on immigrant entrepreneurs' 'concrete embeddedness' in their 'social networks' as well as their 'abstract embeddedness in the socio-economic and politico-institutional environment of the country of settlement'.

A key strength of the embeddedness theory is its ability to locate entrepreneurial actions and processes within specific sets of contexts. This helps answer questions relating to how different contexts and structures like social, cultural, ethnic, legal and policy, among others, both formal and informal in their characteristics, implicate different immigrant entrepreneurial trajectories (Kloosterman et al, 1998). Therefore, in its sense of application, the rise of different immigrant entrepreneurship activities is attributable to the existing different concrete and abstract embeddedness. This implies that different embeddedness begets different mixed embeddedness of immigrants' economic activities (Antwi Bosiakoh \& Williams Tetteh, 2019). Drawing on the idea of different contexts giving rise to different immigrant entrepreneurship trajectories, this study seeks to demonstrate how the existing socio and ethno-cultural realities provide useful pathways for explaining transnational Nigerian immigrant entrepreneurs' embeddedness in Ghana. Next from here, we take a brief detour to understanding Nigerian immigrants in Ghana, followed by the study's research approach before presenting the findings and discussions and finally provide conclusion.

\section{Nigerians in Ghana: migration and economic profile}

Nigeria is located just 45-min flight distance from Ghana eastwards and is separated by two small French-speaking countries, Togo and Benin. Both Ghana and Nigeria share similar colonial past, and are the biggest English-speaking countries in West Africa. The two countries are also, by far, the key players in activities for the formation and operationalization of the sub-regional economic grouping, the Economic Community of West African States, ECOWAS whose main goal is to engender free movement of people and goods across the sub-region. Additionally, Ghana is a lower middle-income economy, and West Africa's second biggest economy after Nigeria (ADB, 2012). Largely, because of these similarities, there is increased migration of Nigerians to Ghana. This migration is further influenced by the peace and stability (Antwi Bosiakoh, 2009) and a much wider range of political and civil liberties in Ghana which have earned the country free status in Freedom in the World ranking (Puddington \& Roylance, 2016). Ghana also has a more superior position than Nigeria in both World Governance Indictors (World Bank, 2016) and Democracy Index (EIU, 2016). But besides these current and evolving realities behind Nigerian migration to Ghana, there is also a historical underpinning to Nigerian migration to Ghana (Antwi Bosiakoh, 2017). Long before colonization and indeed during colonial and post-colonial eras, huge episodes of migratory activities from Nigeria to Ghana were recorded (Amenumey, 2008; Anquandah, 1985; Arhin, 1979), with some research suggesting that, the contemporary trends of Nigerian migration to Ghana is a convenient continuation of the existing historical fact (Antwi Bosiakoh, 2009, 2017). 
Currently, there is an estimated one million Nigerian immigrants in Ghana according to the Nigerian embassy in Accra (Akinyoade, 2015 p. 217). These immigrants cut across the three main ethnic groupings (Igbo, Yoruba and Hausa) in Nigeria. Igbos who are numerically dominant, are mainly resident in Accra and are in flux. They see Ghana as a 'stepping stone' in a broader migratory project to Europe and North America (Akinyoade, 2015 p. 214; Antwi Bosiakoh, 2019). The Yoruba and Hausa immigrants on the other hand appear to see Ghana as another homeland, (Akinyoade, 2015). Self-employment is a common feature of the economic profile of these immigrants (Akinyoade, 2015; Olatuyi et al., 2013). A key factor accounting for this economic profile of Nigerian immigrants in Ghana is the way they themselves perceive Ghana-as a country 'open to investment' (ibid p. 28) where they can achieve their desired upward social mobility. Most of these immigrants are thus involved in unregistered informal trading and business activities (LaPorta \& Schleifer, 2008) within the Ghanaian informal economy. The entrepreneurial activities of the immigrants are embedded in a mix of realities, some of which have been explored recently by focusing on Nigerian women entrepreneurs in Ghana (Antwi Bosiakoh \& Williams Tetteh, 2019), and Nigerian transnational entrepreneurs in Ghana (Antwi Bosiakoh, 2020).

Thus far, one unexplored aspect of this scholarship is the ways in which social and ethno-cultural patterns of Nigerian immigrants, influence their entrepreneurial articulation in Ghana. This is the focus of this paper. Three isolable socio and ethno-cultural themes of relevance are identified for understanding the setting-up and operations of transnational Nigerian immigrants' entrepreneurship in Ghana. These socio and ethnocultural patterns shape different aspects of the business activities of the immigrants such that, it is possible to argue of a 'socio and ethno-cultural embeddedness' of transnational Nigerian immigrants' entrepreneurship in Ghana. This 'socio and ethno-cultural embeddedness' is part of the general mixed embeddedness of Nigerian immigrants' entrepreneurship in the country.

\section{Methods}

We draw this paper from an ethnographic fieldwork by the first author on Nigerian immigrant entrepreneurs in three Ghanaian cities, namely Accra $(n=17)$, Kumasi $(n=14)$ and Ashaiman $(n=10)$. The fieldwork involved a total of 41 entrepreneurs made up of 35 males and 6 females running different businesses in the three cities of Ghana. Selection of the entrepreneurs drew on multiple entry points and contact cases in the first instance. This was to help generate diversity in the activities pursued by the entrepreneurs. Subsequently, and through referrals and snowballing processes, more and more entrepreneurs were identified and included in the study. A final selection strategy involved diversifying the sample by identifying entrepreneurs involved in other business activities. These strategies provided useful pathways for gaining diversity in the activities of the entrepreneurs including those involved in phone/IT accessories trading $(n=12)$, food-related activities $(n=7)$ auto-mobile spare parts trading $(n=6)$, fashion/beauty and entertainment $(n=3)$, metals and hardware $(n=3)$, cleaning and repair $(n=3)$ etc. The fieldwork offered rare opportunities to walk through the various markets the entrepreneurs operate and in the process, engaged in various forms of conversations (casual and in-depth) with the entrepreneurs at their business premises in face to face. Business 
Table 1 Location and sectorial distribution of businesses

\begin{tabular}{|c|c|c|c|c|c|c|c|}
\hline \multirow{2}{*}{$\begin{array}{l}\text { Research } \\
\text { Location }\end{array}$} & \multicolumn{7}{|l|}{ Sectors } \\
\hline & $\begin{array}{l}\text { Phone/IT } \\
\text { accessories }\end{array}$ & $\begin{array}{l}\text { Food } \\
\text { related } \\
\text { activities }\end{array}$ & $\begin{array}{l}\text { Auto } \\
\text { mobile } \\
\text { spares } \\
\text { parts }\end{array}$ & $\begin{array}{l}\text { Fashion/beauty } \\
\text { entertainment }\end{array}$ & $\begin{array}{l}\text { Cleaning } \\
\text { /repairs }\end{array}$ & $\begin{array}{l}\text { Metals/ } \\
\text { hardware }\end{array}$ & Miscellaneo-us \\
\hline Accra & 7 & 3 & - & 2 & 3 & 1 & 1 \\
\hline Kumasi & 4 & 3 & 3 & 1 & - & - & 3 \\
\hline Ashaiman & 1 & 1 & 3 & - & - & 2 & 3 \\
\hline Total & 12 & 7 & 6 & 3 & 3 & 3 & 7 \\
\hline
\end{tabular}

operation activities of the entrepreneurs were also observed to understand the various logics behind them. Table 1 below present the location and sectorial distribution of businesses interviewed.

Besides the 41 entrepreneurs, interviews were also made conducted with leaders of four (4) Nigerian immigrant groups and associations. ${ }^{1}$ Three of these groups/associations, i.e. the Yoruba Association, the Coast City Brothers' Association, and the Nigerian Youth Association, were involved in social and cultural activities and one group/association (the Eagle Digital Association in Tiptoe Lane at Kwame Nkrumah Circle, Accra) involved in business facilitation for its members Additionally, there was interview with the Igbo (Paramount) Chief in Ghana to explore how Nigerian miniature chieftaincy and chiefdoms intersect with the entrepreneurship development activities of their subjects in the country.

In each of the three cities (Accra, Kumasi, and Ashaiman), there were multiple city areas where the entrepreneurs operated. The Kwame Nkrumah Circle area, Legon/East Legon, UTC area, Madina, Kisseman, Tema Station, Haasto and Adenta were the areas in Accra where the entrepreneurs were identified. Similarly, in Kumasi, the entrepreneurs were identified in the Adum/PZ area, Suame Magazine, Suame market area, Kedjetia, Asafo, and Central market. The Ashaiman entrepreneurs were however identified at the Traffic Light and Lebanon Zone 5 areas. The procedures adopted on the field followed international standardise requirements and recommendations, in particular, the Australian National Statement on Ethical Conduct in Human Research (2007, updated in March 2014) as the National Statement, and was approved by the Macquarie University's Human Research Ethics Committee (Human Sciences and Humanities), reference No. 5201400968. While in general the entrepreneurs shared different migration motivation stories anchored on such factors as family, marriage, agency and frustration, among others (Antwi Bosiakoh \& Williams Tetteh, 2019), their life stories in Ghana provide a confluent leitmotif around entrepreneurship.

\section{Results and discussions}

\section{Nigerian immigrants as transnational entrepreneurs in Ghana}

Of the 41 Nigerian immigrant entrepreneurs in this study, approximately $88 \%, n=36$ were involved in one form of transnational practice or the other. This consisted of

\footnotetext{
${ }^{1}$ Names of the entrepreneurs and leaders of the Nigerian immigrant groups /associations have all been anonymized. However, Chief Chukwudi Jude Ihenetu, the Igbo Paramount Chief in Accra insisted his name be mentioned.
} 
Table 2 Transnational patterns of Nigerian entrepreneurs in Ghana

\begin{tabular}{lcclc}
\hline Transnational connections & Accra & Kumasi & Ashaiman & Total \\
\hline Nigeria-Ghana & 4 & 3 & 2 & 9 \\
Nigeria-Ghana; Ghana-Nigeria & 2 & 2 & 1 & 5 \\
A mix of Ghana and Nigeria & 1 & 1 & 1 & 3 \\
Togo-Ghana & 1 & 1 & 0 & 2 \\
China-Ghana & 2 & 2 & 0 & 6 \\
China-Nigeria-Ghana & 1 & 1 & 0 & 3 \\
A mix of Ghana, Nigeria and China & 1 & 2 & 2 & 6 \\
Other countriesa ${ }^{\text {-Ghana }}$ & 2 & 14 & 8 & 36 \\
TOTAL & 14 & & & 6 \\
\hline
\end{tabular}

${ }^{a}$ UK, Japan, UAE, Germany, Singapore, etc.

entrepreneurs whose activities involved movements to and from Nigeria, China, Togo, as well as other countries like the UK, Japan, UAE, Germany, and Singapore, among others. The distribution of these transnational entrepreneurs across the three Ghanaian cities was as follows: Accra 38.8\%, $n=14$; Kumasi 38.8\%, $n=14$; and Ashaiman 22.2\%, $n=8$. This distribution was slightly lower compared to the bigger study's sampling, in particular for Accra and Ashaiman which had 17 and 10 respondents respectively. Overall, a quarter of the transnational entrepreneurs $(25 \%, n=9)$ were involved in GhanaNigeria/Nigeria-Ghana trading activities followed by $16.6 \%, n=6$ each in China-Ghana and Other Countries-Ghana activities. Table 2 below provides detailed information about the activities of transnational Nigerian entrepreneurs in Ghana.

These transnational activities of the entrepreneurs have been discussed and categorized in other studies into three, namely one-way, two-way and tripartite transnationalism (Antwi Bosiakoh, 2020) and how Nigerian entrepreneurs in Ghana respond to emerging economic opportunities occurring both within the West-African economic community, the Economic Community of West African States (ECOWAS) and around the world.

\section{Socio and ethno-cultural embeddedness}

\section{Ethnicity and cultural embeddedness}

The pattern of ethnic and cultural embeddedness of the entrepreneurs across the research sites is mixed in shape. In Accra, the pattern shows Igbo domination and in Kumasi, it is largely Yoruba. However, in Ashaiman, the pattern is more of a blend manifesting both Igbo and Yoruba identities. There were no Hausa ethnic entrepreneurs. For these transnational Nigerian entrepreneurs in Ghana, ethnicity and cultural rationalities play important business set-up and business operation roles. One example to emphasize this position is Obike who runs a Nigerian foodstuff shop in Accra. Obike's business relates directly to concentration of his country people, or better still, his ethnic people in Accra, and specifically the area he operates: 'There are many Nigerians around here and this was one of the things that influenced my establishment of Nigerian food stuffs business here.' Though other ethnics both in Ghana and Nigeria patronise his business, Obike thinks most of his customers are Igbos, his own ethnic people. As he observed, 'Igbos like to cook food in their own house ... we take it as a respect to the home'. This, 
he noted, is a cultural practice, and giving the surge in Nigerian migration to Ghana, he related his business to the food needs of his fellow ethnics:

'The rate of Nigerian migration to Ghana is high so I discovered that if they come, they will need their food and I decided to provide. So, the increased migration of Nigerians to Ghana encouraged me to set up the business. They constitute my customer base ... they will need their Nigerian foods.'

As in Obike's account, Ijeoma (Nigerian restaurant operator) and Ikechukwu (Nigerian foodstuffs shop operator) both anchored the logic of their business identification strategies in the increased migration of Nigerians to Ghana and the expected food needs of the immigrants. This is part of what Kloosterman et al., (1999) call 'market conditions' and reflects how the needs of customers determine the emergence of opportunities in certain segments of the economy. In explaining their decisions to operate Nigerian-specific restaurants and foodstuff shops in Ghana Ijeoma and Ikechukwu noted as follows:

Ijeoma: 'There are a lot of Nigerians working in this precinct and I thought running this kind of business will sell. These Nigerians want to eat something they are used to, their ethnic food?

Ikechukwu: Many Nigerians are in this area and they need their food which we provide so they can enjoy their stay here in Ghana.

These accounts show how the entrepreneurs have embedded their businesses in the 'dense Nigerian ethnic pool' and preference for ethno-cultural products (foods and services) (Marchand \& Siegel, 2014). This is important as businesses need a market to sell their goods and services (Kloosterman, 2010, p. 26). The entrepreneurs have established themselves in the markets where they operate as popular places for 'authentic ethno-cultural specialism' (Barrett, et al., 2002, p. 17) which Nigerian immigrants in Ghana need. This is the beginning of the creation of ethnic niche but better conceived here as sectorial concentration and is related to the oft-mentioned general propensity of immigrant entrepreneurs to enter the food sector to establish ethnic restaurants and groceries (see for example Basu, 2011). Both Ijeoma's and Ikechukwu;s arguments of the desire to consume familiar food from their ethnic/countries of origin (supposedly as it may sound), creates a market niche for entrepreneurial career in ethnic food commerce within immigrants' host country (Basu, 2011). The restaurants and foodstuff activities of Ijeoma and Ikechukwu and others involved in similar activities are ethnically embedded in both the supply and demand sides of market operations. On the supply side, the entrepreneurs implant their businesses in the heritage culture with high premium placed on foodstuffs and raw materials that bear the closest similarity to what comes from Nigeria to create the authentic taste expected by customers at the demand side of the logic.

Besides the food sector, evidence of ethnic embeddedness was detectable in the automobile spare parts business in Suame, Kumasi and in the phone and IT accessories business in the PZ area (Kumasi) and Kwame Nkrumah Circle area, (Accra). These sectors and the locations of concentration serve to attract newly-arrived Nigerian immigrant entrepreneurs. This process contributes to niche formation in certain sectors by the entrepreneurs. Amobi affirmed this, noting that 'there are many of us doing the same 
kind of business here'. Akin to this observation is Abiola's argument produced below as a testament to the ethnic embeddedness line of reasoning.

'Here at Tiptoe Lane, there are more than 300 Nigerian business operatives. We have an association that meets regularly with about 200 registered people and others who have not registered for the association. So yes we are many here. All the shops on this particular lane, except two, are owned by Nigerians, so yes we are many here.' [Abiola, Phone and IT accessories, Kwame Nkrumah Circle, KNC in Accra].

As Razin (2002, p. 163) has noted, accounts on immigrants' inclination to entrepreneurship need to recognise the 'location-specific traits of the immigrant community' and the ways in which immigrants and their businesses 'are inserted into the socio-cultural and institutional context' of their host society (see also Kloosterman, 2010). This observation applies to the discourse on Nigerian immigrant entrepreneurs in this study. Their business set-up and operation narratives are linked to the location-specific traits of 'dense Nigerian ethnic pool' in Ghana and preference for ethnic products. This is a case of 'instituted process between man and his environment' (Polanyi, 1957, p. 248) or more specifically entrepreneurship embedded in ethnic and cultural conditions and rationalities. However, mixed embeddedness as a theoretical construct, underscores the interaction of determinants of entrepreneurship, rather than their separation. Subsequently, we now turn to another aspect of the determinants, so that the nature and complexity of mixed embeddedness may be better explicated.

\section{Embeddedness in informality}

A key part of market structure and market relations in both Ghana and Nigeria is the ways in which informality shapes different aspects of market dynamics. In Ghana for example, informal 'economics' is an accepted part of the economic process and describes many employment forms and economic activities. One estimate of total employment in 1990 was $45 \%$ (Ninsin, 1991), increasing to $89 \%$ in the late 1990s (Yankson et al., 2001). Other estimates point to more than $80 \%$ of all persons employed in Ghana working in the informal sector, with over half (55.9\%) of them in self-employment and a fifth (20.4\%) in family-related enterprises (GSS, 2008; Osei-Boateng \& Ampratwum, 2011 p. 9). In Accra, Grant and Yankson (2003 p. 70) observe that about $40 \%$ of the population were engaged in informal sector economic activities in 2000. Given this informal profile of Ghana's economy, and drawing on the mixed embeddedness frame of thought, informality presents a context which Nigerian immigrant entrepreneurs recognise and use in their business operations. As such most entrepreneurs are involved in the informal sector of market operations since, in the scheme of probability, immigrants generally enter economic frontiers with lower entry barriers (Waldinger, 1984) such as those in the Ghanaian informal economic domain.

Across the three research cities (Accra, Kumasi \& Ashaiman), the pattern of embeddedness in informality was revealing, and manifested in business sizes, family involvement, engagement with officialdom, the formation and operation of informal associations and the way in which informal power brokers shape different aspects of their entrepreneurial activities. For example, all the businesses of the entrepreneurs in this study were small and largely owned individually or by a family. A case in point 
is Adeyemi who operates a Nigerian restaurant at Kiseman at a small suburb north of Accra, drawing on family, informality and transnationality as he describes here:

'My entire family of four (4) is involved in this business ... because I cannot hire and pay salaries now. I and my wife prepare and serve food, wash plates, mop the eating area and clean the tables etc. My son is still in school in Nigeria and he sends badly needed Nigerian foodstuffs to us twice a month. My daughter was brought to Ghana a year ago to learn this business and currently does deliveries and errands.

Adeyemi's account demonstrates concrete informal ways of embedding family/household in his entrepreneurial activities (Welter, 2011). It further illustrates, together with other informal entrepreneurs in this study, the few employees (typically 1-2 employees) they rely on, and the fact that these employees often included family members recruited through the informal system of apprenticeship. Further, he relies on informal transnational family connection to have access to essential resources for his business. But unlike Adeyemi who operates a Nigerian restaurant in Accra, Osita, operates an industrial materials shop in Ashaiman and as a small scale trading entrepreneur, Osita explained how his business relies on informal employment (Welter et al., 2015) in the form of transnational labour recruited through the informal apprenticeship system:

'My business now has 18-years old boy apprentice I brought to Ghana from Nigeria 6 months ago. It is like what we do in Nigeria... you start with an apprentice who works with you for about six years and thereafter, you settle the person by setting up a similar business at a small scale for him.

Also, a key part of the entrepreneurs' discourse on the ease of setting-up their businesses in Ghana is the less-capital requirement: Amobi, Auto-mobile spare parts trader in Kumasi observed that 'In Ghana, one does not need huge capital to start business' This observation, and the perception it carries about capital requirement for setting up business in Ghana, formed a recurring theme in many accounts:

In Ghana, one can set up business with any little money and grow it. I started with GHC500.00 and today, I am in a shop full of goods. This place is better for me than Nigeria. Achebe, $C D$ \& Electrical Shop.

This [business] can be done by anybody with or without money. I started with little money and from that amount, I am what I am today. Nnaji, Hardware Shop.

I think it is very easy to set up business in Ghana. Any amount you have, you can. It is not same in Nigeria. Chinedu, Second-hand Bags (repair \& sale).

Though these narratives make sense on their own, they are more meaningful when viewed within the context of informality. In formal reality, there are legal/formal requirements for setting up business in the country including (but not limited to) investment capital threshold for immigrants and other sector-specific requirements for business set-up and this makes business entry less easy. Thus, the immigrant entrepreneurs in this study do not meet these requirements and thus operate outside the legal/formal domain of the economy (Godfrey, 2011), i.e. in the informal 
Table 3 Matrix of informality: business/tax registration and account statuses

\begin{tabular}{|c|c|c|c|}
\hline & $\sqrt{ }$ & & $x$ \\
\hline & \multicolumn{2}{|c|}{ Business registration status } & \\
\hline RGD & 3 & & 38 \\
\hline GIPC & 2 & & 39 \\
\hline \multirow[t]{2}{*}{ BOP } & 16 & & 25 \\
\hline & & Tax registration status & \\
\hline LGU & & 14 & \\
\hline \multirow[t]{2}{*}{ DTRD of GRA } & & 13 & \\
\hline & & Account status & \\
\hline No formal account records & & 29 & \\
\hline Some accounts recorded & & 9 & \\
\hline Full accounts recorded & & 3 & \\
\hline
\end{tabular}

space where no threshold (like capital, etc.) is placed on them and therefore they can operate with whatever capital at their disposal. Furthermore, social relations and networks provide immigrant entrepreneurs access to social capital that are embedded in a network (Aarstad et al., 2010). Thus, the entrepreneurs' accounts position Ghana more as conducive for their informal small medium and micro enterprises (SMMEs) they operate and the canticles of 'less capital requirement' helps place this argument in empirical frame.

Consequently, most entrepreneurs, in taking advantage of this situation, are 'locked up' in small scale informal businesses. Further, most businesses were neither registered with the Registrar General's Department (RGD), the Ghanaian institution mandated with business registration responsibility, nor with the Ghana Investment Promotion Centre (GIPC) which is responsible for investment facilitation in the country (Table 3). However, some business operatives produced Business Operation Permits (BOP) issued by local government units (LGUs), namely the Accra Metropolitan Assembly, the Kumasi Metropolitan Assembly and the Ashaiman Municipal Assembly. Largely because they are unregistered, most businesses evade tax (LaPorta \& Schleifer, 2008), and engage in corrupt practices, particularly in the cross-border movements of goods, services and their people.

Table 3 also shows that only a third of the businesses are registered for tax purposes with the relevant local government unit $(34 \% ; n=14)$ and the Domestic Tax Revenue Division of the Ghana Revenue Authority ( $32 \% ; n=13)$, and for many entrepreneurs, keeping record of business activities is not part of their normal practices. These characteristics support the construction of informal economy as involving unregistered firms hidden from taxation and even when registered, some entrepreneurs still evade taxes (LaPorta \& Schleifer, 2008; Overå, 2007, p. 543), manipulate established norms and exploit loopholes. 


\section{Informal power brokers}

A key part of the broader governance structure of Nigerian immigrant entrepreneurship in Ghana is the way in which informal power brokers shape different aspects of the entrepreneurial activities. As part of their adaptation, and the need to preserve their cultural labels, Nigerian migrants in Ghana, through various ethnic associations, have created different miniature groups and chiefdoms in Ghana. Perhaps, the most prominent of these is the Igbo Paramountcy in Accra. Chief Chukwudi Jude Ihenetu operates the Ghana palace of the Igbo Paramountcy in East Legon, Accra. He and his elders sit with other sub-chiefs in Igbo community meetings to discuss and resolve matters of interest to Igbos in Ghana. There are similar community meetings in the regions and Igbo leaders and members submit to the Igbo Central in Accra. Recently, Chief Ihenetu has been involved in the creation of sub-chiefs at La-Nkwantanan-Madina Sempe, Dansoman, Amrahia- Adoteiman, and Ashaiman chiefs to take care of the needs of his people. Key among these needs is to provide them with education on basic requirements for peaceful living in Ghana:

...we are working to educate our people about living in Ghana, like the need to have updated documentation to make our people law abiding.

\section{口 Chief Chukwudi Jude Ihenetu.}

As a businessman himself, Chief Ihenetu, who first came to Ghana in 1995 engaged in the supply of auto-mobile spare parts. After convincing himself about the conducive business environment in Ghana, he decided to settle and now owns businesses dealing in mother care products, oil, and aluminium products. He is also involved in the Ezeigbo Foundation which helps young Igbo boys to learn various trades and further provide capital for them to start their own businesses. Many of Chief Ihenetu's sub-chiefs, like himself, are also business people and they provide business advice to their subjects.

Besides the miniature chiefdom, there are several informal structures for organising Nigerian immigrants and their entrepreneurial activities in Ghana. The Yoruba Association in Kumasi, the Eagle Digital Association at Tiptoe Lane at Kwame Nkrumah Circle in Accra, the Coast City Brothers' Association in Kumasi, and the Nigerian Youth Association are but a few such structures. Interview with some association leaders revealed that their activities intersect multiple frontiers like education, immigrant integration, business, law, etc. For example, Jamal, a senior member of the Yoruba Association in Kumasi indicated that, the association, through the education they give to their members', help them 'to understand their Ghanaian host, especially their culture, and to be able to relate better with them in the running of their businesses to prevent conflict'. Also, Baba, an executive member of the Eagle Digital Association in Tiptoe Area at Kwame Nkrumah Circle, Accra intimated that, members of the association are always enjoined to live peacefully with their Ghanaian host, and 'to identify peaceful options always in resolving conflicts both in their business dealings and in their places of residence'. Baba further noted that, 'leaders of the association sometimes mediates for members who have cases with the police or in court.' This point was corroborated by a senior member of the Coast City Brothers' Association who further indicated that their association 'organize a program once a year to refresh members on peaceful living and some basic Ghanaian laws'. 
Therefore, together with the heads of ethnic chiefdoms and their sub-chiefs, these informal power bearers arbitrate in disputes between their member-subjects as well as between their member-subjects and their Ghanaian business counterparts. As largely trading entrepreneurs, these business people frequently encounter problems with the Ghanaian Customs and Police officials, and Nigerian Chiefs in Ghana and leaders of the associations have regularly intervened to resolve them out of court (Antwi Bosiakoh, 2011). These activities and services serve as contextual realities and a part of the mixed embeddedness argument that enhance the economic activities of the entrepreneurs in the country. This is a case of informal power brokers involved in 'peace-making' and business facilitation, two important strands of the mixed embeddedness of transnational Nigerian immigrant entrepreneurship in Ghana.

\section{Traditional apprenticeship system}

For Nigerian immigrant entrepreneurs in Ghana, a key part of the articulation of culture in their entrepreneurial activities is the deployment of their traditional apprenticeship system for the recruitment of labour transnationally. This system, derived from a philosophy where individuals including the socially deprived, can negotiate better social status (Uchendu, 2007), is applied in real world market situation. Here, parents 'bargain and negotiate with successful traders' and business people (Oga, master, Nna Ukwu, big father/master) to pass their skills on to young apprentices (Odibo, or just 'Boys' as this often involves young males) through a certain process, which has been described by Agozino and Anyanike (2007, p. 236) as a traditional Igbo business school. In this practice, an $\mathrm{Oga}$ (e.g. in auto-mobile spare parts business) recruits young apprentices for training from Nigeria (usually for five to seven years) and serially replaces them as they become adroit in the business (Agozino \& Anyanike, 2007; Forrest, 1994; Olutayo, 1999). During the period of apprenticeship, the Oga provides the needs of his Odibo, including shelter and boarding as well as transportation and healthcare. However, there is no salary payment but the Oga helps the Odibo to set-up their own businesses.

This cultural system (Krueger Jr, 2000; Weber, 1930) is deployed as an important entrepreneurial training pathway and transnational labour recruitment strategy and almost all the entrepreneurs shared in it. Kelechi, for example, operates an informal event management at Accra's north-east suburb of Haatso and indicated that he had two boys working as apprentices with him in the beginning of his business but currently has only one boy who has been with him for the eight months before he was interviewed. Kelechi speaks about the utility of this apprenticeship system as follows:

'Honestly, my business benefited from our apprenticeship system. I had two boys from Nigeria to help me when I started. One is now at Teshie and the other is back to school at Jayee University. I have another boy currently working with me'. Kelechi, Event Management, Accra.

Similar to the account of Kelechi, Ibeamaka, who runs an auto-mobile spare-parts business at Suame magazine in Kumasi, indicated that his business relies greatly on the use of the apprenticeship system. Ibeamaka has two shops, all located at Suame and he has two apprentices for each shop as sales assistants. He notes that, the use of the apprentices as sales assistants helps him to focus on matters relating to his supply chain, moving from 
Kumasi through Accra to Lagos where he gets most of his goods, and back. Ibeamaka points out that:

I am forever grateful for the system as it helps in this business operations. I don't know how I would make it in this business if I were to hire all the four sales assistants and pay them monthly salaries.' Ibeamaka, Auto-mobile Spare-parts shop owner, Kumasi.

Besides Kelechi and Ibeamaka, other entrepreneurs shared experiences on the use of apprentices in business operations as something they had done before or currently do, or that they know people who had done so in the past, or are doing it currently, or they had heard about people doing it now or in the past.

Indeed, for some entrepreneurs like Osita and Abiola, the narratives of their entrepreneurial journeys began with their own training under trade masters through this informal apprenticeship system, and like their own training, they also rely on this system to satisfy their cultural obligation to fellow ethnics and countrymen. As is evident thus far in the narratives, the entrepreneurs, in addition, rely on this system to meet their labour needs. While this often involves family members, it suffices to say that it is mainly for people from the same ethnic group (like an Igbo entrepreneur with Igbo apprentices), and most commonly from the same federal State, town or village like an entrepreneur and apprentices from a town or village in Anambra State. Kelechi's current apprentice for example was brought from a village near his own hometown. Most entrepreneurs had at least one apprentice-employee but others had more. Those without any Odibo hoped to have one in the future when their businesses expand. This is because, the entrepreneurs know the usefulness of the apprenticeship system to the growth of their businesses.

Thus, the deployment of this apprenticeship system adds two important breadths of explanation to the discourse on immigrant entrepreneurship. First is to the cultural explanation of immigrant entrepreneurship, that is how cultural backgrounds (Basu \& Altinay, 2002; Marchand \& Siegel, 2014), and in this case the culturally devised system of apprenticeship (Agozino \& Anyanike, 2007) implicates the entrepreneurial development processes of the transnational Nigerian immigrant entrepreneurs in Ghana. The second, and perhaps the most important in this paper is to the mixed embeddedness construction of the immigrants' entrepreneurial articulations in the country. The informal apprenticeship system provides important informal context for understanding the entrepreneurs' business set-up and operational logics.

\section{Discussion}

From its beginning, the mixed embeddedness approach conceived immigrant entrepreneurship as the outcome of the matching process between entrepreneurs themselves, and the existing/potential opportunities within the socio-economic and politico-institutional environments (Kloosterman et al., 1999). This position provides a basis for understanding immigrant entrepreneurship away from the separate explanatory factors emanating from specific fields like economics, culture, psychology, technology, among others, and also from specific socio-cultural and politico-institutional and policy/legal contexts. From this idea, we are able to locate the Nigerian immigrant entrepreneurship 
in this study within a mix of social and ethno-cultural contexts that speak to an intraAfrican reality of mixed embeddedness and immigrant entrepreneurship.

This African-centred reality of mixed embeddedness and immigrant entrepreneurship rolls out first from the immigrants' concentration at particular areas to set up businesses. From the data of this study, we draw two-fold explanations for this point. The first explanation is the way it offers basis for setting up businesses that meet the basic needs of the immigrants themselves within the concentrated area. This is a case of how market conditions within the particular areas of concentration by the immigrants determine what business opportunities can be pursued (Barrett, et al., 2002; Kloosterman, 2010; Kloosterman et al., (1999; Marchand \& Siegel, 2014). As an ample testament to this position, the coming of Nigerian immigrant to Ghana and their concentration in large numbers have provided favourable context for their ethnically and culturally inspired food entrepreneurship. This food entrepreneurship carries important cultural meaning, not least as an identity marker for the immigrants in the country (Ojo, 2018). The second stream of explanation for immigrants drawing on their concentration at particular areas relates to transfer of business knowledge. Concentrated areas often attract newly arrived immigrants and this has implications not only for adjustment and network formation but also opportunity identification, business entry pathways and niche formation through informal skills uptake processes, etc.

Another strand of the mixed embeddedness emanating from the social and ethno-cultural study of Nigerian immigrant entrepreneurship in Ghana is informality, i.e. how the entrepreneurs draw on various forms of informality in their operations. Key contours of informal imprints identified in this study relates to the sizes of the enterprises pursued by the entrepreneurs and the few employees including the recruitment processes which draw on the entrepreneurs' informal traditional system of apprenticeship. A further mark of informality underlining the operation of Nigerian immigrant entrepreneurship in Ghana is the way family/household members are embedded both domestically and in transnational context that connects the entrepreneurs' home country. Also related to informality is the way different shades of informal power brokers shape different aspects of their entrepreneurial activities through facilitations and peace-building in the business environment within which the entrepreneurs operate.

The final strand of the mixed embeddedness rationalities in the operation of Nigerian immigrant entrepreneurship in Ghana is in the role of traditional apprenticeship system operating both within the family context and as community norm/cultural label, and embodying transnational life-force. From these positions, it is possible to posit a socio and ethno-cultural mixed embeddedness treatise for understanding the transnational Nigerian immigrant entrepreneurs in Ghana. This treatise, properly explained, hitches on a multi-level concept aggregated around the three actualities of dense ethnic pool, informality and informal power brokerage and traditional apprenticeship system. And while the discussions here are all important to the scholarship on mixed embeddedness and immigrant entrepreneurship, we point out two areas of particular interest. The first is that, the mixed embeddedness of the transnational entrepreneurs is anchored in spatial space. This argument in itself, is laden with dual construal. The first is that, the mixed embeddedness of the transnational entrepreneurs straddle across all the three research sites of Accra, Kumasi and Ashaiman and the second relating to transnationalism, i.e. the 
far reaching West African, Africa and far off places around the world. The second contribution of this paper to the mixed embeddedness scholarship is in the application of the theory to a non-Western setting, specifically in a developing country context of Ghana. This contribution is essential because, the existing empirical application of the mixed embeddedness theory to immigrant entrepreneurship focuses mainly on developed economies in western democracies, particularly in Europe and North America, among others. While some aspects of this African-centred actuality of mixed embeddedness and immigrant entrepreneurship (e.g. dense ethnic concentration and informality, etc.) corroborates the extant scholarship (Barrett et al., 2002; Basu, 2011; Kloosterman, 2010; Marchand \& Siegel, 2014; Welter, 2011), other aspects of this African-centred representation (e.g. the traditional apprenticeship system and the role of informal power brokers) are quite novel, potentially carrying important imperative for the discourse on mixed embeddedness and immigrant entrepreneurship. With this representation, the discourse on mixed embeddedness and immigrant entrepreneurship which is less reflective of the actualities in developing country contexts is broadened, and taken together with other issues discussed, this paper casts important light on the nature of immigrant entrepreneurship within the south-south migration discourse.

\section{Conclusion}

This paper is an attempt to understand the socio and ethno-cultural underpinnings (dense ethnic pool, informality and traditional apprenticeship system) of entrepreneurial activities pursued by Nigerian immigrants in three Ghanaian cities, Accra, Kumasi and Ashaiman. These immigrant entrepreneurs across the three research sites, were first and foremost, transnational in the operation of their businesses as their businesses connect multiple national (Ghana, Nigeria, Togo, China, etc.) and continental (Africa, Asia, Europe) localities. Within continental Africa, the entrepreneurs are deeply embedded in the West African sub-region, such that, their activities, reflecting the contextual conditions in the sub-region can be said to be embedded within the West African states. As transnational entrepreneurs as they are, they maintain business-related linkages with their country of origin, Nigeria and the country of origin (Ghana) as well as Togo and others far off in Asia and Europe. By this, they transform isolable geographical places into transnational, trans-local or multi-local space for performing their entrepreneurship that utilized embeddedness essences drawn from their social and ethno cultural patterns.

Going into the future, migration policy positions of West African governments need to recognize not only the economic implications of migration within the sub-region but also the social and ethno-cultural specificities that envelop these migratory configurations. This is because of the ways in which the lines of socio and ethno-cultural patterns provide useful pathways for understanding the formation, operations and future prospects of entrepreneurship pursued by the immigrants and the broader transnational (mixed) embeddedness argument of the entrepreneurs in West Africa. 


\section{Funding}

This work was supported by Macquarie University, Sydney, Australia, through its International Macquarie Research Excellence Scholarship (iMQRES) Grant Number 2014037 to the first author.

\section{Availability of data and materials}

The dataset used for this study are available from the corresponding author on reasonable request.

\section{Declarations}

\section{Competing interest}

The authors declare that they have no competing interests.

\section{Author details}

${ }^{1}$ Department of Sociology, Macquarie University, Sydney, Australia. ${ }^{2}$ Department of Business Management, Ghana Institute of Management and Public Administration (GIMPA), Accra, Ghana.

Received: 19 January 2021 Accepted: 1 November 2021

Published online: 28 December 2021

\section{References}

Aarstad, J., Haugland, S. A., \& Greve, A. (2010). Performance spillover effects in entrepreneurial networks: Assessing a dyadic theory of social capital. Entrepreneurship Theory and Practice, 34(5), 1003-1020.

African Development Bank (ADB) (2012). Republic of Ghana Country Strategic Paper: 2012-2016. Abidjan: Country Operations Department, African Development Bank Group.

Agozino, B., \& Anyanike, I. (2007). IMU AHIA: Traditional lgbo business school and global commerce culture. Dialectical Anthropology, 31(1-3), 233-252.

Akinyoade, A. (2015). Nigerians in transit: The trader and the religious in Jerusalem House, Ghana. In A. Akinyoade \& J.-B. Gewald (Eds.), African roads to prosperity: People en route to socio-cultural and economic transformations (pp. 211-231). Brill: Leiden.

Aliaga-Isla, R., \& Rialp, A. (2013). Systematic review of immigrant entrepreneurship literature: Previous findings and ways forward. Entrepreneurship \& Regional Development: An International Journal, 25(9-10), 819-844.

Amenumey, D. E. K. (2008). Ghana: A concise history from pre-colonial times to the 20th century. Woeli Publishing Services.

Anquandah, J. (1985). Ethnoarchaeological Clues to Ghana's great past and-A greater future? University of Ghana Monographs and papers in African Archaeology, No. 2, Department of Archaeology, University of Ghana.

Antwi Bosiakoh, T. (2019). Nigerian immigrants as 'liminars' in Ghana, West Africa: Narratives on mobility, immobility and borderlands. Journal of Asian \& African Studies. https://doi.org/10.1177/0021909619827036

Antwi Bosiakoh, T. (2009). Understanding migration motivations in West Africa: The case of Nigerians in Ghana. Legon Journal of Sociology, 3(2), 93-112.

Antwi Bosiakoh, T. (2011). The role of migrant associations in adjustment, integration and social development: The case of Nigerian migrant associations in Accra, Ghana. Ghana Journal of Development Studies, 8(2), 64-83.

Antwi Bosiakoh, T. (2017). Nigerian Immigrant Entrepreneurs in Contemporary Ghana: Insights on Locational/Sectoral Niches and Inter-Generational (Dis) Continuities. Urban Forum, 28(2), 143-163.

Antwi Bosiakoh, T. (2020). Transnational embeddedness of Nigerian immigrant entrepreneurship in Ghana, West Africa. Journal of International Migration and Integration, 21, 1187-1204.

Antwi Bosiakoh, T., \& Williams Tetteh, V. (2019). Nigerian immigrant women's entrepreneurial embeddedness in Ghana, West Africa. International Journal of Gender and Entrepreneurship, 11(1), 38-57.

Arhin, K. (1979). West African traders in Ghana in the nineteenth and twentieth centuries. Longman.

Barrett, G., Jones, T., McEvoy, D., \& McGoldrick, C. (2002). The economic embeddedness of immigrant enterprise in Britain. International Journal of Entrepreneurial Behaviour and Research, 8(1/2), 11-31.

Basu, A. (2011). From "break out" to "breakthrough:" Successful market strategies of immigrant entrepreneurs in the UK. International Journal of Entrepreneurship, 15, 59-81.

Basu, A., \& Altinay, E. (2002). The interaction between culture and entrepreneurship in London's immigrant businesses. International Small Business Journal, 20(4), 371-393.

Chacko, E. (2015). Ethiopian taxicab drivers: Forming an occupational niche in the US Capital. African and Black Diaspora, 9(2), 200-213

Economist Intelligence Unit (EIU). (2016). Democracy Index 2015 Democracy in an age of anxiety. The Economist Intelligence Unit.

Forrest, T. G. (1994). The advance of African capital: The growth of Nigerian private enterprise. University of Virginia Press.

Ghana Statistical Service (GSS) (2008): Ghana Living Standards Survey: Report of the Fifth Round (V). Accra: Ghana Statistical Service.

Godfrey, P. C. (2011). Toward a theory of the informal economy. The Academy of Management Annals, 5(1), $231-277$.

Granovetter, M. (1985). Economic action and social structure: The problem of embeddedness. American Journal of Sociology, 91(3), 481-510.

Grant, R., \& Yankson, P. (2003). City profile: Accra. Cities, 20(1), 65-74.

Jones, T., Ram, M., Edwards, P., Kiselinchev, A., \& Muchenje, L. (2014). Mixed embeddedness and new migrant enterprise in the UK. Entrepreneurship \& Regional Development, 26(5-6), 500-520.

Kloosterman, R. C. (2003a). Creating opportunities. Policies aimed at increasing openings for immigrant entrepreneurs in the Netherlands. Entrepreneurship \& Regional Development, 15(2), 167-181. 
Kloosterman, R. C. (2003b). Mixed embeddedness and post-industrial opportunity structures trajectories of migrant entrepreneurship in Amsterdam. In S. Musterd \& W. Salet (Eds.), Amsterdam human capital (pp. 311-330). Amsterdam University Press.

Kloosterman, R. C. (2010). Matching opportunities with resources: A framework for analyzing (migrant) entrepreneurship from a mixed embeddedness perceptive. Entrepreneurship \& Regional Development, 22(1), 25-45.

Kloosterman, R., \& Rath, J. (2001). Immigrant entrepreneurs in advanced economies: Mixed embeddedness further explored. Journal of Ethnic and Migration Studies, 27(2), 189-201.

Kloosterman, R., Van der Leun, J., \& Rath, J. (1998). Across the border: Immigrants' economic opportunities, social capital and informal business activities. Journal of Ethnic and Migration Studies, 24(2), 249-268.

Kloosterman, R., Van Der Leun, J., \& Rath, J. (1999). Mixed embeddedness:(in) formal economic activities and immigrant businesses in the Netherlands. International Journal of Urban and Regional Research, 23(2), 252-266.

Krueger Jr, N. F. (2000). The cognitive infrastructure of opportunity emergence. Entrepreneurship: Theory and Practice, 24(3):5-23.

LaPorta, R., \& Schleifer, A. (2008). The Unofficial Economy and Economic Development, Working Paper Series, pp. 1-75. Washington, DC: National Bureau of Economic Research.

Marchand, K., \& Siegel, M. (2014). Immigrant Entrepreneurship in Cities. Background paper to World Migration Report 2015. International Organization for Migration (IOM). https://www.iom.int/sites/default/files/our_work/ICP/MPR/WMR2015-Background-Paper-KMarchand-MSiegel.pdf

Moyo, I. (2014). A Case Study of Black African Immigrant Entrepreneurship in Inner City Johannesburg Using the Mixed Embeddedness Approach. Journal of Immigrant \& Refugee Studies, 12(3), 250-273.

Ninsin, K. (1991). The informal sector in Ghana's political economy. Freedom Publications.

Ojo, S. (2018). Identity, ethnic embeddedness, and African Cuisine Break-Out in Britain. Journal of Foodservice Business Research, 21(1), 33-54.

Olatuyi, A., Awoyinka, Y., \& Adeniyi, A. (2013). Nigerian diasporas in the South: Harnessing the potential for national development. Research Report No. ACPOBS/2013/PUB06. ACP Observatory on Migration and International Organization for Migration.

Olutayo, O. A. (1999). The lgbo entrepreneur in the political economy of Nigeria. African Study Monographs, 20(3), $147-174$.

Osei-Boateng, C., \& Ampratwum, E. (2011). The informal sector in Ghana. Accra: Friedrich Ebert Stiftung Ghana Office.

Overå, R. (2007). When men do women's work: structural adjustment, unemployment and changing gender relations in the informal economy of Accra, Ghana. The Journal of Modern African Studies, 45(4), 539-563.

Peters, N. (2002). Mixed embeddedness: Does it really explain immigrant enterprise in Western Australia (WA)? International Journal of Entrepreneurial Behavior \& Research, 8(1/2), 32-53.

Polanyi, K. (1957). The economy as instituted process. In K. Polanyi, C. M. Arensberg, \& H. W. Pearson (Eds.), Trade and market in the early empires: Economies in history and theory (pp. 243-270). Henry Regnery Company.

Price, M., \& Chacko, E. (2009). The mixed embeddedness of ethnic entrepreneurs in a new immigrant gateway. Journal of Immigrant \& Refugee Studies, 7(3), 328-346.

Puddington, A., \& Roylance, T. (2016). Freedom in the world 2016 - Anxious dictators, wavering democracies: Global freedom under pressure. Washington D.C.: Freedom House.

Razin, E. (2002). The economic context, embeddedness and immigrant entrepreneurs. International Journal of Entrepreneurial Behavior \& Research, 8(1/2), 162-167.

Uchendu, V. C. (2007). Ezi na ulo: The extended family in Igbo civilization. Dialectical Anthropology, 31(1-3), 167-219.

Waldinger, R. (1984). Immigrant enterprise in the New York garment industry. Social Problems, 32(1), 60-71.

Waldinger, R., Aldrich, H., \& Ward, R. (1990). Opportunities, group characteristics, and strategies. In R. Waldinger, H. Aldrich, \& R. Ward (Eds.), Ethnic Entrepreneurs: Immigrant Business in Industrial Societies (pp. 13-48). Sage Publications.

Weber, M. (1930). The Protestant Ethic and the Spirit of Capitalism. Scribner.

Welter, F. (2011). Contextualizing entrepreneurship - conceptual challenges and ways forward. Entrepreneurship Theory \& Practice, 35(1), 165-184.

Welter, F., Small lbone, D., \& Pobol, A. (2015). Entrepreneurial activity in the informal economy: A missing piece of the entrepreneurship jigsaw puzzle. Entrepreneurship \& Regional Development, 27(5-6), 292-306.

World Bank Group. (2016). Worldwide Governance Indicators. World Bank.

Yankson, P. W. K., Lareya, A., \& Aryeetey, E. (2001). State of human development. In A. Sawyer (Ed.), Ghana human development report 2000. UNDP and ISSER: Accra.

\section{Publisher's Note}

Springer Nature remains neutral with regard to jurisdictional claims in published maps and institutional affiliations. 